\title{
Effect of different solutions on color stability of acrylic resin-based dentures
}

\section{Marcelo Coelho GOIATO Adhara Smith NÓBREGA Daniela Micheline dos SANTOS Agda Marobo ANDREOTTI Amália MORENO}

Department of Dental Materials and Prosthodontics, Araçatuba Dental School, Univ Estadual Paulista - UNESP, Araçatuba, SP, Brazil.

Declaration of Interests: The authors certify that they have no commercial or associative interest that represents a conflict of interest in connection with the manuscript.

Corresponding Author: Marcelo Coelho Goiato

E-mail: goiato@foa.unesp.br

http://dx.doi.org/10.1590/S1806-83242013005000033 Epub Dec 17, 2013

Submitted: Apr 30, 2013

Accepted for publication: Sep 28, 2013

Last revision: Oct 14, 2013
Abstract: The aim of this study was to evaluate the effect of thermocycling and immersion in mouthwash or beverage solutions on the color stability of four different acrylic resin-based dentures (Onda Cryl, OC; QC20, QC; Classico, CL; and Lucitone, LU). The factors evaluated were type of acrylic resin, immersion time, and solution (mouthwash or beverage). A total of 224 denture samples were fabricated. For each type of resin, eight samples were immersed in mouthwashes (PlaxColgate, PC; Listerine, LI; and Oral-B, OB), beverages (coffee, CP; cola, $\mathrm{C}$; and wine, $\mathrm{W}$ ), and artificial saliva (AS; control). The color change $(\Delta \mathrm{E})$ was evaluated before (baseline) and after thermocycling $\left(\mathrm{T}_{1}\right)$, and after immersion in solution for $1 \mathrm{~h}\left(\mathrm{~T}_{2}\right), 3 \mathrm{~h}\left(\mathrm{~T}_{3}\right), 24 \mathrm{~h}\left(\mathrm{~T}_{4}\right), 48 \mathrm{~h}\left(\mathrm{~T}_{5}\right)$, and $96 \mathrm{~h}\left(\mathrm{~T}_{6}\right)$. The CIE Lab system was used to determine the color changes. The thermocycling test was performed for 5000 cycles. Data were submitted to three-way repeated-measures analysis of variance and Tukey's test $(p<0.05)$. When the samples were immersed in each mouthwash, all assessed factors, associated or not, significantly influenced the color change values, except there was no association between the mouthwash and acrylic resin. Similarly, when the samples were immersed in each beverage, all studied factors influenced the color change values. In general, regardless of the solution, LU exhibited the greatest $\Delta \mathrm{E}$ values in the period from $\mathrm{T}_{1}$ to $\mathrm{T}_{5}$; and QC presented the greatest $\Delta \mathrm{E}$ values at $\mathrm{T}_{6}$. Thus, thermocycling and immersion in the various solutions influenced the color stability of acrylic resins and QC showed the greatest color alteration.

Descriptors: Denture, Complete; Polymers; Coloring Agents.

\section{Introduction}

For many years, acrylic resin has been successfully used for denture fabrication. It has many advantages, like its ease of manipulation, ${ }^{1,2}$ low cost, adequate physical and mechanical properties, biocompatibility, and satisfactory appearance., ${ }^{3,4}$ However, these materials exhibit, over time, unsatisfactory characteristics such as loss of elasticity, abrasion, porosity, and color change. ${ }^{5,6}$

Color stability is one of the most important clinical properties for dental materials, and color change may be an indicator of aging or damaging of materials., ${ }^{1,27-9}$ Furthermore, the aesthetic appearance of a prosthesis is certainly an important feature required by patients and must satisfy their expectations. ${ }^{10}$ 
The color change of a polymeric material may be caused by intrinsic and extrinsic factors. Intrinsic factors involve resin discoloration itself and matrix changes, ${ }^{1,2}$ occurring during the aging process of the material due to many physical and chemical conditions. Furthermore, extrinsic factors such as thermal changes, stain accumulation, artificial dyes used in food, cleaning procedures, and handling by the patient can also cause discoloration. . $, 6,11-14^{-14}$

It has been reported that thermocycling ${ }^{1,14,15}$ and contact with mouthwashes ${ }^{16-20}$ and beverages ${ }^{15,20-22}$ influence the color change of resin. Thus, oral hygiene and eating habits must be considered in order to preserve most of the acrylic resin properties, such as color stability, hardness, and durability, among others. For example, hygiene and habits have been correlated to the color stability of acrylic resins. ${ }^{2,16,23}$ However, little is known regarding the color stability of acrylic resin-based dentures that have been in contact with beverages and mouthwashes.

The aim of this study was to evaluate the effect of themocycling as well as immersion in beverages and mouthwashes on the color stability of acrylic resinbased dentures to test the hypothesis that themocycling and immersion in coloring agents will influence the color stability of acrylic resin-based dentures.

\section{Methodology}

In this study, a total of 224 specimens (56 of each type of acrylic resin) that were medium pink in color were fabricated according to the manufacturer's instructions (Table 1). For each brand of resin, samples $(n=8)$ were submitted to thermocycling and immersed in artificial saliva (AS; control) or one of six solutions (Table 2).

For sample fabrication, silicone rubber disks (Zetalabor, Badia Polesine, Italy) with dimensions of $30 \times 3 \mathrm{~mm}$ were added to flasks (Vipi, Pirassununga, Brazil) that were filled with dental stone (Vigodent, Rio de Janeiro, Brazil), and impressions were created. ${ }^{1,6,9}$ The acrylic resin material was packed into the molds, and the polymerization cycles were performed (Table 1).

Next, the samples were stored in distilled water in a bacteriological incubator (Cienlab, Campinas, Brazil) at $37^{\circ} \mathrm{C} \pm 1^{\circ} \mathrm{C}$ for $24 \mathrm{~h}$. Excess sample was removed with a Maxi-Cut abrasive drill (Vicking, São Paulo, Brazil), and surfaces were polished using a sequence of metallographic sandpapers in an automated polishing machine (Arotec, Cotia, Brazil) for $1 \mathrm{~min}$ for each sandpaper with constant water irrigation and a speed of $300 \mathrm{rpm} .{ }^{1,6,9}$

Color changes were evaluated by visible ultraviolet refraction spectrophotometry with a UV-2450 reflectance spectrophotometer (Shimadzu, Nakagyo-ku, Japan). ${ }^{1,69,24,25}$ Color changes were calculated according to the International Commission on Illumination.

The color stability test was performed before and after thermocycling and at the end of each immersion period. Color change $(\Delta \mathrm{E})$ was calculated for the following time periods: from baseline to after thermocycling $\left(\mathrm{T}_{1}\right)$; and from after thermocycling to after immersion for $1 \mathrm{~h}\left(\mathrm{~T}_{2}\right), 3 \mathrm{~h}\left(\mathrm{~T}_{3}\right), 24 \mathrm{~h}$ $\left(\mathrm{T}_{4}\right), 48 \mathrm{~h}\left(\mathrm{~T}_{5}\right)$, and $96 \mathrm{~h}\left(\mathrm{~T}_{6}\right)$.

The CIE Lab system allows color perception in three-dimensional space through a wavelength versus refraction index. The " $\mathrm{L}$ " axis is luminosity and ranges from 0 to 100 , the "a" coordinate is the quantity of red and green, and the " $\mathrm{b}$ " coordinate is the quantity of yellow and blue. ${ }^{26}$ The CIE Lab system calculates color variation between two points, based on the following formula:

$$
\Delta E=\left[(\Delta L)^{2}+(\Delta a)^{2}+(\Delta b)^{2}\right]^{1 / 2}
$$

Table 1 - Polymers and polymerization procedures used in this study.

\begin{tabular}{l|l|l}
\hline Material & Manufacturer & Polymerization procedure \\
\hline Onda Cryl (OC) & $\begin{array}{l}\text { Classico Dental Products, São Paulo, } \\
\text { Brazil }\end{array}$ & $\begin{array}{l}\text { Microwave polymerization: } 3 \text { min at 30\% power; } \\
4 \text { min at 0\% power, and } 3 \text { min at } 60 \% \text { power }\end{array}$ \\
\hline QC20 (QC) & Dentsply Ltda., Rio de Janeiro, Brazil & Immerse flask in water at $100^{\circ} \mathrm{C}$ for 20 min \\
\hline Classico (CL) & $\begin{array}{l}\text { Classico Dental Products, São Paulo, } \\
\text { Brazil }\end{array}$ & $\begin{array}{l}\text { Immerse flask in cold water, maintain in low heat for } 30 \text { min. Turn off heat } \\
\text { for a further } 30 \text { min, and then heat until boiling for } 1 \mathrm{~h}\end{array}$ \\
\hline Lucitone (LU) & Dentsply Ltd., Rio de Janeiro, Brazil & Immerse flask in water at $73^{\circ} \mathrm{C}$ for 90 min and at $100^{\circ} \mathrm{C}$ for $30 \mathrm{~min}$ \\
\hline
\end{tabular}


Table 2 - Solutions used in this study.

\begin{tabular}{l|l}
\hline Solutions & Manufacturer \\
\hline Coffee Pilão (CP) & Sara Lee, Jundiaí, Brazil \\
\hline Cola soft drink (C) & Coca-Cola, Ribeirão Preto, Brazil \\
\hline Periquita dry red wine (W) & José Maria da Fonseca Vinhos S.A., Azeitão, Portugal \\
\hline Colgate Plax Fresh Mint (PC) & Colgate-Palmolive, São Bernardo do Campo, Brazil \\
\hline Listerine ${ }^{\circledast}$ Cool Mint (LI) & Johnson \& Johnson, São José dos Campos, Brazil \\
\hline Oral-B $^{\circledR}-$ mint flavor - Alcohol free (OB) & Eurofarma, Itapevi, Brazil \\
\hline Artificial saliva (AS) & Farmácia Manipulação Apothicário, Araçatuba, Brazil \\
\hline
\end{tabular}

Delta values were calculated based on the difference between the final and baseline values for each coordinate $\left(L^{*}, a^{*}\right.$, and $\left.b^{*}\right)$.

After the initial color test, the samples were submitted to thermocycling (Convel, Araçatuba, Brazil) for 5000 cycles, simulating 5 years of clinical use. ${ }^{13}$ Each cycle consisted of alternating $30 \mathrm{~s}$ baths with a temperature between $5^{\circ} \mathrm{C} \pm 1^{\circ} \mathrm{C}$ and $55^{\circ} \mathrm{C} \pm 1^{\circ} \mathrm{C}$, simulating thermal changes that occur in the oral cavity. ${ }^{1}$ Immediately after thermocycling, new color stability readings were performed $\left(\mathrm{T}_{1}\right)$.

Samples were immersed in one of three beverages $(\mathrm{CP}, \mathrm{C}$, and $\mathrm{W})$ and one of three mouthwashes (PC, LI, and OB; Table 2). Furthermore, eight samples were immersed in AS as a control.

Each sample was placed in a container containing $25 \mathrm{~mL}$ of the test solution, and the container was closed to prevent evaporation ${ }^{10}$ and placed in a solution agitator (Cienlab, Campinas, Brazil). ${ }^{18}$ The samples were immersed in solutions for 1, 3, 24, 48, and $96 h{ }^{1,23}$ and agitated for 2 min every $3 h .{ }^{18}$ After each period, the solutions were changed, the samples were washed with water and dried with a paper towel, and new color evaluations were performed.

A three-way repeated-measures analysis of variance was performed using SPSS 21.0 statistics software (IBM Corporation, New York, USA) to verify if there were significant differences among the studied factors (resins, dye solutions, and time). The Tukey-Kramer honestly significant difference test was used as a post-hoc test. All data were analyzed at a significance level of 0.001 .

\section{Results}

Tables 3 and 5 show that all evaluated factors and the interactions among them significantly affected the color change values $(p<0.001)$, except that mouthwash was not associated with resin.

For the $\mathrm{QC}$ resin, $\mathrm{T}_{6}$ significantly influenced the color change values, independent of the immersion solution, compared to the other resins and time periods analyzed (Tables 4 and 6).

Table 3 - Three-way repeated-measures analysis of variance of acrylic resins in mouthwash.

\begin{tabular}{l|c|c|c|c|c}
\hline \multicolumn{1}{|c|}{ Source } & df & SS & MS & $F$ & P \\
\hline Mouthwash & 3 & 16.02 & 5.34 & 6.63 & $<0.001^{*}$ \\
\hline Resin & 3 & 271.16 & 90.39 & 112.25 & $<0.001^{*}$ \\
\hline Mouthwash $\times$ resin & 9 & 11.99 & 1.33 & 1.65 & 0.109 \\
\hline Between subjects & 112 & 90.18 & 0.81 & & \\
\hline Period & 5 & 404.58 & 80.92 & 335.22 & $<0.001^{*}$ \\
\hline Period $\times$ mouthwash & 15 & 34.80 & 2.32 & 9.61 & $<0.001^{*}$ \\
\hline Period $\times$ resin & 15 & 1058.82 & 70.59 & 292.43 & $<0.001^{*}$ \\
\hline Period $\times$ mouthwash $\times$ resin & 45 & 90.65 & 2.01 & 8.35 & $<0.001^{*}$ \\
\hline Within subjects & 560 & 135.17 & 0.24 & & $<$ \\
\hline
\end{tabular}

$p<0.001$ denotes a statistically significant difference; $d f$, degrees of freedom; SS, sum of squares; MS, mean squares; F, F-statistic value; $p$, p-statistic value. 
Table 4 - Color changes (mean values \pm standard deviation) of each acrylic resin in each mouthwash.

\begin{tabular}{|c|c|c|c|c|c|c|c|}
\hline \multirow{2}{*}{ Mouthwash } & \multirow{2}{*}{ Resin } & \multicolumn{6}{|c|}{ Period of time } \\
\hline & & $\mathrm{T}_{1}$ & $\mathrm{~T}_{2}$ & $\mathrm{~T}_{3}$ & $\mathrm{~T}_{4}$ & $\mathrm{~T}_{5}$ & $T_{6}$ \\
\hline \multirow{4}{*}{ AS } & OC & $0.60 \pm 0.15^{\mathrm{ABa}}$ & $0.33 \pm 0.14^{\mathrm{Aa}}$ & $0.42 \pm 0.18^{\mathrm{Aa}}$ & $0.54 \pm 0.17^{\mathrm{Aa}}$ & $0.67 \pm 0.13^{\mathrm{Aa}}$ & $0.69 \pm 0.36 \mathrm{Aa}$ \\
\hline & QC & $1.06 \pm 0.42^{\mathrm{ABa}}$ & $0.52 \pm 0.16^{\mathrm{Aa}}$ & $0.63 \pm 0.16^{\mathrm{Aa}}$ & $0.66 \pm 0.14^{\mathrm{Aa}}$ & $0.75 \pm 0.28 \mathrm{Aa}$ & $5.12 \pm 0.59 \mathrm{Db}$ \\
\hline & $\mathrm{CL}$ & $0.94 \pm 0.40 \mathrm{ABa}$ & $0.48 \pm 0.22^{\mathrm{Aa}}$ & $0.93 \pm 0.30 \mathrm{Aba}$ & $0.96 \pm 0.32 \mathrm{Aba}$ & $0.97 \pm 0.40^{\mathrm{ABa}}$ & $0.98 \pm 0.37 \mathrm{ABa}$ \\
\hline & LU & $1.78 \pm 0.33^{\mathrm{ABa}}$ & $2.07 \pm 0.67 \mathrm{Ba}$ & $2.08 \pm 0.53 \mathrm{Ba}$ & $2.30 \pm 0.28^{\mathrm{BCa}}$ & $2.17 \pm 0.22 \mathrm{Ba}$ & $1.54 \pm 0.70 \mathrm{ABCa}$ \\
\hline \multirow{4}{*}{ LI } & OC & $0.79 \pm 0.20 \mathrm{Aa}$ & $0.59 \pm 0.23 \mathrm{Aa}$ & $0.65 \pm 0.29 \mathrm{Aa}$ & $0.68 \pm 0.24 \mathrm{Aa}$ & $0.77 \pm 0.52{ }^{A B a}$ & $0.98 \pm 0.53 \mathrm{ABa}$ \\
\hline & QC & $0.78 \pm 0.20 \mathrm{Aa}$ & $0.49 \pm 0.09 \mathrm{Aa}$ & $0.92 \pm 0.17^{\mathrm{Aba}}$ & $1.20 \pm 0.51 \mathrm{ABCa}$ & $0.53 \pm 0.06 \mathrm{Aa}$ & $7.72 \pm 0.31 \mathrm{~Eb}$ \\
\hline & $\mathrm{CL}$ & $1.11 \pm 0.28^{\mathrm{ABab}}$ & $0.50 \pm 0.11^{\mathrm{Aa}}$ & $1.90 \pm 0.38^{\mathrm{Bb}}$ & $1.15 \pm 0.43^{\mathrm{ABab}}$ & $1.33 \pm 0.54 \mathrm{ABCab}$ & $1.87 \pm 0.84 \mathrm{ABCb}$ \\
\hline & LU & $1.85 \pm 0.42^{\mathrm{ABa}}$ & $2.14 \pm 0.53^{\mathrm{Ba}}$ & $2.10 \pm 0.63 \mathrm{Ba}$ & $1.95 \pm 0.65^{\mathrm{Ba}}$ & $2.11 \pm 0.65^{\mathrm{Ba}}$ & $2.30 \pm 0.82 \mathrm{BCa}$ \\
\hline \multirow{4}{*}{ PC } & OC & $0.61 \pm 0.19 \mathrm{ABa}$ & $0.64 \pm 0.23 \mathrm{Aa}$ & $0.65 \pm 0.27 \mathrm{Aa}$ & $0.66 \pm 0.21 \mathrm{Aa}$ & $0.64 \pm 0.08 \mathrm{Aa}$ & $1.69 \pm 0.75 \mathrm{ABCa}$ \\
\hline & QC & $0.36 \pm 0.09 \mathrm{ABa}$ & $0.36 \pm 0.09 \mathrm{Aa}$ & $0.36 \pm 0.16 \mathrm{Aa}$ & $0.50 \pm 0.24 \mathrm{Aa}$ & $0.74 \pm 0.17^{\mathrm{Aa}}$ & $8.97 \pm 0.73^{\mathrm{Fb}}$ \\
\hline & $\mathrm{CL}$ & $1.13 \pm 0.69 \mathrm{ABa}$ & $0.95 \pm 0.24 \mathrm{ABa}$ & $0.91 \pm 0.39 \mathrm{Aba}$ & $0.80 \pm 0.34 \mathrm{Aa}$ & $1.00 \pm 0.33^{\mathrm{ABa}}$ & $1.05 \pm 0.71 \mathrm{ABa}$ \\
\hline & LU & $1.99 \pm 0.57 \mathrm{ABa}$ & $2.65 \pm 0.33^{\mathrm{BCa}}$ & $2.56 \pm 0.46^{\mathrm{BCDa}}$ & $2.44 \pm 0.55^{\mathrm{BCa}}$ & $2.41 \pm 0.56^{\mathrm{BCa}}$ & $2.12 \pm 0.87 \mathrm{ABCa}$ \\
\hline \multirow{4}{*}{ OB } & OC & $0.80 \pm 0.35 \mathrm{Aa}$ & $0.69 \pm 0.30 \mathrm{Aa}$ & $0.74 \pm 0.24 \mathrm{Aa}$ & $0.59 \pm 0.08{ }^{A a}$ & $0.62 \pm 0.25^{A a}$ & $0.57 \pm 0.24 \mathrm{Aa}$ \\
\hline & QC & $0.75 \pm 0.21^{\mathrm{Aa}}$ & $0.74 \pm 0.25^{\mathrm{Aa}}$ & $0.63 \pm 0.16^{\mathrm{Aa}}$ & $0.61 \pm 0.22^{A a}$ & $0.61 \pm 0.18^{A a}$ & $10.33 \pm 3.12^{\mathrm{Gb}}$ \\
\hline & $\mathrm{CL}$ & $1.10 \pm 0.51 \mathrm{ABa}$ & $1.17 \pm 0.76^{\mathrm{ABa}}$ & $1.21 \pm 0.61 \mathrm{ABCa}$ & $1.26 \pm 0.53 \mathrm{ABCa}$ & $1.24 \pm 0.59 \mathrm{ABa}$ & $1.21 \pm 0.83 \mathrm{ABCa}$ \\
\hline & LU & $2.04 \pm 0.52 \mathrm{Ba}$ & $2.31 \pm 0.31 \mathrm{Ba}$ & $2.37 \pm 0.54 \mathrm{BCa}$ & $2.08 \pm 0.13 \mathrm{Ba}$ & $2.52 \pm 0.53^{\mathrm{BCa}}$ & $2.13 \pm 0.60 \mathrm{Ba}$ \\
\hline
\end{tabular}

The same superscripted capital letters in the same column and lower-case letters in the same line represent a statistically significant difference at a $0.1 \%$ level of significance $(p<0.001)$ by Tukey's test.

\section{Discussion}

Thermocycling and immersion in mouthwash or beverage solutions caused color changes in the acrylic resins that increased throughout the study (Tables 4 and 6). These color changes might be related to extrinsic factors that cause discoloration, such as absorption and adsorption of water, ${ }^{6,11,12}$ and to intrinsic factors, like changes in cast or material ageing. ${ }^{12,14,16}$ Furthermore, thermocycling can promote volumetric contraction and expansion of materials, leading to degradation. ${ }^{14-16,19}$

When water molecules are absorbed by acrylic resin, they act like plasticizers to damage the material's mechanical resistance through the formation of microcracks related to absorption and hydrolytic degradation of the polymer, resulting in linkage cleavage and gradual deterioration of its infrastructure. ${ }^{3,4}$

Table 5 - Three-way repeated-measures analysis of variance of the color changes of acrylic resins in beverages.

\begin{tabular}{l|c|c|c|c|c}
\hline \multicolumn{1}{c|}{ Source } & df & SS & MS & $F$ & $p$ \\
\hline Beverage & 3 & 25.02 & 8.34 & 18.62 & $<0.001^{*}$ \\
\hline Resin & 3 & 453.08 & 151.03 & $337.20<$ & $<0.001^{*}$ \\
\hline Beverage $\times$ resin & 9 & 26.40 & 2.93 & 6.55 & $<0.001^{*}$ \\
\hline Between subjects & 112 & 50.16 & 0.45 & & \\
\hline Period & 5 & 260.77 & 52.15 & 275.46 & $<0.001^{*}$ \\
\hline Period $\times$ beverage & 15 & 20.79 & 1.39 & 7.32 & $<0.001^{*}$ \\
\hline Period $\times$ resin & 15 & 609.41 & 40.63 & 214.58 & $<0.001^{*}$ \\
\hline Period $\times$ beverage $\times$ resin & 45 & 42.12 & 0.94 & 4.94 & $<0.001^{*}$ \\
\hline Within subjects & 560 & 106.03 & 0.19 & & \\
\hline
\end{tabular}

${ }^{*} p<0.001$ denotes a statistically significant difference; df, degrees of freedom; $S S$, sum of squares; MS, mean squares; F, F-statistic value; $p, p$-statistic value. 
Table 6 - Color changes (mean values \pm standard deviation) of each acrylic resin in each beverage.

\begin{tabular}{|c|c|c|c|c|c|c|c|}
\hline \multirow{2}{*}{ Beverage } & \multirow{2}{*}{ Resin } & \multicolumn{6}{|c|}{ Period of time } \\
\hline & & $\mathrm{T}_{1}$ & $\mathrm{~T}_{2}$ & $\mathrm{~T}_{3}$ & $\mathrm{~T}_{4}$ & $\mathrm{~T}_{5}$ & $T_{6}$ \\
\hline \multirow{4}{*}{ AS } & OC & $0.60 \pm 0.15^{\mathrm{Aa}}$ & $0.33 \pm 0.14 \mathrm{Aa}$ & $0.42 \pm 0.08 \mathrm{Aa}$ & $0.54 \pm 0.17^{\mathrm{Aa}}$ & $0.67 \pm 0.22^{A B a}$ & $0.69 \pm 0.25 \mathrm{Aa}$ \\
\hline & $Q C$ & $1.06 \pm 0.52^{\mathrm{Aba}}$ & $0.52 \pm 0.15^{\mathrm{Aa}}$ & $0.63 \pm 0.06 \mathrm{Aa}$ & $0.66 \pm 0.24 \mathrm{Aa}$ & $0.75 \pm 0.12^{\mathrm{ABa}}$ & $5.12 \pm 0.59 \mathrm{cb}$ \\
\hline & $\mathrm{CL}$ & $0.94 \pm 0.40 \mathrm{Aa}$ & $0.48 \pm 0.18^{\mathrm{Aa}}$ & $0.93 \pm 0.22 \mathrm{Aa}$ & $0.96 \pm 0.32 \AA$ & $0.97 \pm 0.40 \mathrm{ABa}$ & $0.98 \pm 0.37 \mathrm{Aa}$ \\
\hline & LU & $1.78 \pm 0.33^{\mathrm{Ba}}$ & $2.07 \pm 0.67^{\mathrm{Ba}}$ & $2.08 \pm 0.53^{\mathrm{Ba}}$ & $2.30 \pm 0.68 \mathrm{Ca}$ & $2.17 \pm 0.22 \mathrm{BCa}$ & $1.54 \pm 0.70 \mathrm{Aa}$ \\
\hline \multirow{4}{*}{$\mathrm{CP}$} & OC & $0.70 \pm 0.35^{\mathrm{Aa}}$ & $0.55 \pm 0.14^{\mathrm{Aa}}$ & $0.59 \pm 0.20^{\mathrm{Aa}}$ & $0.68 \pm 0.09 \mathrm{Aa}$ & $0.70 \pm 0.16^{\mathrm{ABa}}$ & $0.76 \pm 0.20 \mathrm{Aa}$ \\
\hline & $Q C$ & $0.99 \pm 0.36 \mathrm{Aa}$ & $0.49 \pm 0.16 \mathrm{Aa}$ & $1.34 \pm 0.40 \mathrm{ABa}$ & $0.84 \pm 0.29 \mathrm{ABa}$ & $0.95 \pm 0.31 \mathrm{ABa}$ & $6.09 \pm 1.28 \mathrm{CDb}$ \\
\hline & $\mathrm{CL}$ & $1.17 \pm 0.28 \mathrm{ABa}$ & $0.40 \pm 0.18 \mathrm{Aa}$ & $0.76 \pm 0.35 \mathrm{Aa}$ & $0.95 \pm 0.25^{\mathrm{ABa}}$ & $1.19 \pm 0.43 \mathrm{Ba}$ & $1.38 \pm 0.30 \mathrm{Aa}$ \\
\hline & LU & $1.80 \pm 0.49 \mathrm{Ba}$ & $3.96 \pm 1.33^{\mathrm{Bbc}}$ & $2.76 \pm 0.49$ BCabd & $2.89 \pm 0.41 \mathrm{CDd}$ & $2.17 \pm 0.22{ }^{\mathrm{BCad}}$ & $3.32 \pm 0.83 \mathrm{Bbc}$ \\
\hline \multirow{4}{*}{ C } & OC & $0.68 \pm 0.41^{\mathrm{Aa}}$ & $0.59 \pm 0.23^{\mathrm{Aa}}$ & $0.61 \pm 0.25^{\mathrm{Aa}}$ & $0.66 \pm 0.22 \mathrm{Aa}$ & $0.59 \pm 0.21^{\mathrm{ABa}}$ & $0.78 \pm 0.27^{\mathrm{Aa}}$ \\
\hline & $Q C$ & $0.82 \pm 0.35^{\mathrm{Aa}}$ & $0.48 \pm 0.12^{\mathrm{Aa}}$ & $0.47 \pm 0.11^{\mathrm{Aa}}$ & $0.43 \pm 0.15^{\mathrm{Aa}}$ & $0.52 \pm 0.26^{\mathrm{ABa}}$ & $7.04 \pm 0.42^{\mathrm{Db}}$ \\
\hline & $\mathrm{CL}$ & $1.18 \pm 0.62 \mathrm{ABa}$ & $0.85 \pm 0.41^{\mathrm{Aa}}$ & $0.57 \pm 0.30 \mathrm{Aa}$ & $0.82 \pm 0.17^{\mathrm{ABa}}$ & $0.82 \pm 0.35^{\mathrm{ABa}}$ & $1.10 \pm 0.88^{\mathrm{Aa}}$ \\
\hline & LU & $1.96 \pm 0.33^{\mathrm{Ba}}$ & $3.50 \pm 0.72^{\mathrm{BCb}}$ & $3.30 \pm 0.46 \mathrm{Cb}$ & $3.13 \pm 0.68 \mathrm{CDab}$ & $3.45 \pm 0.51 \mathrm{Dab}$ & $2.80 \pm 0.37^{\mathrm{Bab}}$ \\
\hline \multirow{4}{*}{ W } & OC & $0.64 \pm 0.44 \mathrm{Aa}$ & $0.46 \pm 0.25^{\mathrm{Aa}}$ & $0.58 \pm 0.20 \mathrm{Aa}$ & $0.80 \pm 0.38 \mathrm{ABa}$ & $0.77 \pm 0.10^{\mathrm{ABa}}$ & $0.82 \pm 0.29 \mathrm{Aa}$ \\
\hline & $Q C$ & $0.96 \pm 0.38 \mathrm{Aa}$ & $0.54 \pm 0.16^{\mathrm{Aa}}$ & $0.50 \pm 0.25^{\mathrm{Aa}}$ & $0.47 \pm 0.08^{\mathrm{Aa}}$ & $0.83 \pm 0.36^{\mathrm{ABa}}$ & $6.75 \pm 0.62^{\mathrm{Db}}$ \\
\hline & $\mathrm{CL}$ & $0.89 \pm 0.42^{\mathrm{Aab}}$ & $0.56 \pm 0.11^{\mathrm{Aa}}$ & $1.23 \pm 0.49 \mathrm{ABabc}$ & $1.66 \pm 0.44^{\mathrm{BCC}}$ & $2.33 \pm 0.62 \mathrm{ccd}$ & $2.77 \pm 0.85^{\mathrm{Bd}}$ \\
\hline & LU & $2.06 \pm 0.59 \mathrm{Ba}$ & $2.89 \pm 0.81 \mathrm{Cab}$ & $2.86 \pm 0.53 \mathrm{BCab}$ & $3.47 \pm 1.08 \mathrm{Db}$ & $3.43 \pm 0.54 \mathrm{Db}$ & $2.80 \pm 0.37 \mathrm{Bab}$ \\
\hline
\end{tabular}

The same superscripted capital letters in the same column and lower-case letters in the same line represent a statistically significant difference at a $0.1 \%$ level of significance $(p<0.001)$ by Tukey's test.

The LU resin showed the greatest $\Delta \mathrm{E}$ values from $\mathrm{T}_{1}$ to $\mathrm{T}_{5}$, and QC showed the greatest $\Delta \mathrm{E}$ values at $\mathrm{T}_{6}$ (Tables 4 and 6 ). The variance between brands regarding susceptibility to color change may be justified by the different product compositions. The color change of LU may be due to its molecular structure, which favors water absorption and has a greater porosity due to the release of residual monomer. ${ }^{27,28}$ Moreover, the components used for chemical activation in addition to thermal activation, contained in the short-cycle resins, may be responsible for the results shown by the QC resin. ${ }^{29}$ These results are in agreement with those by Hersek et al., ${ }^{20}$ who evaluated the color stability of acrylic resins in three colorants used in food and verified that LU followed by QC presented the greatest color changes.

There is evidence that beverages and some artificial colorants used in food may increase the staining of acrylic resin. ${ }^{1,20-22,29}$ The dark pigment of $\mathrm{W}$ and its low $\mathrm{pH}$ can cause drastic staining, negatively affecting the surface integrity by softening the matrix. ${ }^{20} \mathrm{In}$ this study, only OC did not show a statistically significant color change when immersed in W (Table 6). Similarly, Imirzalioglu et al. ${ }^{2}$ evaluated the pigmentation ability of acrylic resins when immersed in coffee, tea, and nicotine and verified visual color changes in all samples after immersion in dye solution.

Our statistical analysis demonstrated that the immersion time period was associated with the mouthwashes, which caused material degradation that interfered with color stability (Table 3). These results show that these differences were due to the material structure and the time period, not to the mouthwashes themselves (Table 4). It is important to highlight that even the control group showed a color change. Absorption may be the major cause of color change due to the polarity of the acrylic re$\sin { }^{7}$ Color alteration occurred owing to water molecules in the mouthwashes and AS, which acted like plasticizers as previously explained. ${ }^{16}$

Although it was not statistically significant, it was observed that the beverages $\mathrm{C}$ and $\mathrm{CP}$ caused more intense color alterations of the resins. $C$ may have al- 
tered the resin color because its low $\mathrm{pH}$ possibly affects the surface integrity of the material. ${ }^{1}$ Regarding $\mathrm{CP}$, its chemistry changes under different conditions, such as storage time, temperature, and humidity. In addition, caffeine and caffeic acid in coffee may cause discoloration of polymeric materials. ${ }^{1-3}$

There are controversies regarding setting an unsatisfactory clinical value for the derived color. ${ }^{3,14,28}$ Goldstein and $\mathrm{Schmit}^{30}$ state that $\Delta \mathrm{E}$ values greater than 3.7 are not clinically acceptable. Based on the results of this study, QC undergoes a major color change when immersed in coloring agents. Thus, caution is needed regarding its indication for making denture bases.

This in vitro study only simulated a clinical condition in which many other factors can affect color; thus, it has its limitations. It is important to emphasize that other factors, isolated or associated, such as poor cleaning of prosthesis ${ }^{1,2,8,10}$ components, particles of the oral environment, ${ }^{13,16,19}$ material porosity associated with the fabrication technique, ${ }^{18,21}$ surface flaws of the material, ${ }^{16,21}$ and the polishing surface $^{17}$ may influence the color stability of acrylic resins. Therefore, additional studies must be performed to evaluate the chemical interactions between coloring agents and acrylic resins.

\section{Conclusion}

In conclusion, thermocycling alone provided a color change of the acrylic resin. In addition, all factors (acrylic resin, immersion time, and solution), associated or not, influenced the color change of the acrylic resins assessed, except that mouthwash was not associated with the acrylic resin. Finally, the QC resin suffered the greatest color change, which was clinically noticeable at the end of immersion in solution for 96 $h$. Thus, caution is needed regarding its indication.

\section{Acknowledgements}

This study was supported by Fundação de Amparo à Pesquisa do Estado de São Paulo - FAPESP, grant number 2010/16962-8, Brazil. 


\section{References}

1. Goiato MC, Zuccolotti BC, Moreno A, Santos DM, Pesqueira AA, Dekon SFC. Colour change of soft denture liners after storage in coffee and coke. Gerodontology. 2011 Jun;28(2):140-5.

2. Imirzalioglu P, Karacaer O, Yilmaz B, Ozmen I. Color stability of denture acrylic resins and a soft lining material against tea, coffee, and nicotine. J Prosthodont. 2010 Feb;19(2):118-24.

3. Robinson JG, McCabe JF, Storer R. Denture bases: the effects of various treatments on clarity, strength and structure. J Dent. 1987 Aug;15(4):159-65.

4. Smith LSA, Saver JA. Sorbed water and mechanical behaviour of poly(methyl methacrylate). Plast Rubber Process Appl. 1986 Mar;6(1):57-65.

5. Hong G, Murata H, Li Y, Sadamori S, Hamada T. nfluence of denture cleansers on the color stability of three types of denture base acrylic resin. J Prosthet Dent. 2009 Mar; 101(3):205-13.

6. Goiato MC, Santos DM, Baptista GT, Moreno A, Andreotti AM, Bannwart LC, et al. Effect of thermal cycling and disinfection on colour stability of denture base acrylic resin. Gerodontology. 2012 Apr 23. DOI: 10.1111/j.1741-2358.2012.00676.x. Epub ahead of print.

7. Oguz S, Mutluay MM, Dogan OM, Bek B. Color change evaluation of denture soft lining materials in coffee and tea. Dent Mater J. 2007 Mar;26(2):209-16.

8. Waliszewski M. Restoring dentate appearance: a literature review for modern complete denture esthetics. J Prosthet Dent. 2005 Apr;93(4):386-94.

9. Goiato MC, Santos DM, Haddad MF, Pesqueira AA. Effect of accelerated aging on the microhardness and color stability of flexible resins for dentures. Braz Oral Res. 2010 Jan-Mar;24(1):114-9.

10. Heydecke G, Locker D, Awad MA, Lund JP, Feine JS. Oral and general health-related quality of life with conventional and implant dentures. Community Dent Oral Epidemiol. 2003 Jun;31(3):161-8.

11. Makila E, Honka O. Clinical study of a heat-cured silicone soft lining material. J Oral Rehabil. 1979 Apr;6(2):199-204.

12. Wagner WC, Kawano F, Dootz ER, Koran A 3rd. Dynamic viscoelastic properties of processed soft denture liners: Part II-Effect of aging. J Prosthet Dent. 1995 Sep;74(3):299-304.

13. Knott NJ. The durability of acrylic complete denture bases in practice. Quintessence Int. 1989 May;20(5):341-3.

14. Shimizu H, Kakigi M, Fujii J, Tsue F, Takahashi Y. Effect of surface preparation using ethyl acetate on the shear bond strength of repair resin to denture base resin. J Prosthodont. 2008 Aug;17(6):451-5.

15. Mariatos G, Frangou M, Polyzois G, Papadopoulos T. Evaluation of shear bond strength of microwaveable acrylic resins in denture repair: a comparative study. Acta Odontol Scand. 2006 Aug;64(4):244-8.
16. Gürdal P, Akdeniz BG, Hakan Sen B. The effects of mouthrinses on microhardness and colour stability of aesthetic restorative materials. J Oral Rehabil. 2002 Sep;29(9):895-901.

17. Cavalcanti AN, Mitsui FH, Ambrosano GM, Mathias P, Marchi GM. Effect of different mouthrinses on Knoop hardness of a restorative composite. Am J Dent. 2005 Dec;18(6):338-40.

18. Colucci V, Santos CD, Amaral FL, Corona SA, Catirse AB. Influence of $\mathrm{NaHCO} 3$ powder on translucency of microfilled composite resin immersed in different mouthrinses. J Esthet Restor Dent. 2009;21(4):242-8.

19. Gürdal P, Akdeniz BG, Hakan Sen B. The effects of mouthrinses on microhardness and colour stability of aesthetic restorative materials. J Oral Rehabil. 2002 Sep;29(9):895-901.

20. Hersek N, Canay S, Uzun G, Yildiz F. Color stability of denture base acrylic resins in three food colorants. J Prosthet Dent. 1999 Apr;81(4):375-9.

21. Keyf F, Etikan I. Evaluation of gloss changes of two denture acrylic resin materials in four different beverages. Dent Mater. 2004 Mar;20(3):244-51.

22. Purnaveja S, Fletcher AM, Ritchie GM, Amin WM, Moradians S, Dodd AW. Color stability of two self-curing denture base materials. Biomaterials. 1982 Oct;3(4):249-50.

23. Oguz S, Mutluay MM, Dogan OM, Bek B. Color change evaluation of denture soft lining materials in coffee and tea. Dent Mater J. 2007 Mar;26(2):209-16.

24. Fernandes AU, Goiato MC, Batista MA, Santos DM. Color alteration of the paint used for iris painting in ocular prostheses. Braz Oral Res. 2009 Oct-Dec;23(4):386-92.

25. Mancuso DN, Goiato MC, Santos DM. Color stability after accelerated aging of two silicones, pigmented or not, for use in facial prostheses. Braz Oral Res. 2009 Apr-Jun;23(2):144-8.

26. Nimeroff I. Propagation of errors in spectrophotometric colorimetry. J Opt Soc Am.1953 Jun;43(6):531-3.

27. Barbosa DB, Souza RF, Pero AC, Marra J, Compagnoni MA. Flexural strength of acrylic resins polymerized by different cycles. J Appl Oral Sci. 2007 Oct;15(5):424-8.

28. Bayraktar G, Guvener B, Bural C, Uresin Y. Influence of polymerization method, curing process, and length of time of storage in water on the residual methyl methacrylate content in dental acrylic resins. J Biomed Mater Res B Appl Biomater. 2006 Feb;76(2):340-5.

29. Neppelenbroek KH, Pavarina AC, Gomes MN, Machado AL, Vergani CE. Bond strength of hard chairside reline resins to a rapid polymerizing denture base resin before and after thermal cycling. J Appl Oral Sci. 2006 Dec;14(6):436-42.

30. Goldstein GR, Schmitt GW. Repeatability of a specially designed intraoral colorimeter. J Prosthet Dent. 1993 Jun;69(6):616-9. 